\title{
Asian Catholic Universities Meet in Indonesia
}

\section{Dan Ross, SJ.}

Daniel Ross, S J. is Jesuit Conference of East Aria secretory for tertiory educotion. College of Theology Fu Jen University Hsinchuang, Toipeihsien 242 Taiwan. Fax: 8862906 5371; email: danrossepc2. hinet.net.

$\mathbf{I}_{\mathrm{i} \text { i }}^{\mathrm{n}}$ the summer of 1992 a group of 10presidents of Cathoic universities in Eastern Asia met at a retreat house in the mountains of northern Taiwan. Represented were Korea, Japan, Taiwan, the Philippines, Indonesia, and Thailand-countries in the area where there are Catholic universities. Under the inspiration of Bill Byron, S.J., then of the Catholic University of America, the group brainstormed the idea of forming an association that would cross borders in Asia in a new way. The result was the Association of Southeast and East Asian Catholic Universities (ASEACU). One year later, we held ow first annual meeting at Assumption University in Thailand. Twentysix institutions took part. The next year, in August 1994, the second meeting was held in Bacolod City, The Philippines. Thisyear we met in Yogyakarta, Indonesia and made plans for ASEACU '96 in Seoul, Korea. More than 30 universities and a few colleges have now joined ASEACU, and each year has seen a maturing of the association. There were 54 participants at this year's meeting, representing 29 schools. Another 8 member schools were not able to attend. Also with us was the secretary of the regional association of eleven Catholic universities in Indonesia.

One matter Cardinal Dormaatmadia stressod was the question of retaining our cultural roots while confronted with unprecedented economic development.

Two major papers supplied the material for much discussion at the meeting in Yogyakarta. Julius Cardinal Darmaatmadja, S.J., president of the Indonesian Bishops' Conference, gave a well-received paper on the subject of "Improving Moral Responsibility of Catholic University Alumni." The Cardinal provided us with a broad picture of the social realities confronting our educational institutions in an age of globalization. One matter he stressed was the question of retaining our cultural roots while confronted with unprecedented economic development. Fr. Joseph Pittau, S.J., Rector of the Gregorian University in Rome, spoke on the "Role of Catholic University Alumni in Pluralistic Communities in Asia of the 21 st Century."
Fr. Pittau is past president of Sophia University in Tokyo and gave many references to his experiences heading large and well-respected universities in both the East and the West. Fr. Pittau was especially helpful in describing the place of Catholic schools staffed mostly by non-Catholics and for students who are, for the most part, non-Catholic. With the exception of the Philippines, this is a reality we are all facing in East Asia.

Pilot studies on the influence ow East Asian schools have had on alumni were undertaken during this past year. Preliminary results were presented and discussed for research done in, Taiwan, the Philippines, Indonesia, and Thailand. The data from these studies, while incomplete, were the background for much discussion. This led to a choice of a theme for next year, "Responses of the ASEACU institutions to Our Rapidly Changing Societies." Resolutions were also passed at this year's meeting to add our voice in support of such projects as those working for the banning of the production and use of land mines as well as pumng an end to nuclear testing. There was discussion on possible projects for the cooperative efforts of ASEACU member schools.

Five ASEACU member institutions are supporting faculty training for Phnom Penh University. This university is run by the Cambodian government and is the only university in that country. In this project we are trying to look outward from our group of Catholic universities toward those who are most in need of our support. A group of six faculty members from Phnom Penh University are presently the Ateneo de Manila under the sponsorship of five different ASEACU schools from Japan, Korea, Taiwan, Indonesia and the Philippines. Two more Cambodian teachers are alreadyinto their second year in a computer science program at the Ateneo.

ASEACU' 96 will take place from August 23 to 25,1996 in Seoul, Korea. The Catholic University of Korea and Sogang University will cohost the meeting. The tremendous cultural diversity in East Asia would seem to argue against cooperative efforts such as ASEACU, and in the past that might have been true. The last few years, however, have seen a "we can do it" spirit growing that reaches from the countries of the north with few Christians, through the Catholic majority in the Philippines, to the largestMuslim country in the world, Indonesia. Economically, things are alive. There are also accompanying social changes that challenge both the identity of our Catholic schools and the way that we go about our mission; both content and method are under scrutiny. 